\title{
Studi Run-Up Gelombang Pada Bangunan Jetty Pelabuhan di PPP (Pelabuhan Perikanan Pantai) Tegalsari, Kota Tegal
}

\author{
Bagaskoro Cahyo Fauzan*, Warsito Atmodjo, Baskoro Rochaddi, Rikha Widiaratih, dan Azis Rifai \\ Departemen Oseanografi, Fakultas Perikanan dan Ilmu Kelautan, Universitas Diponegoro \\ Jl. Prof. H. Soedarto, S.H, Tembalang Semarang. 50275 Telp/fax (024)7474698 \\ Email: *bagascf@students.undip.ac.id
}

\begin{abstract}
Abstrak
Bangunan pelindung pantai jetty pelabuhan di Pelabuhan Perikanan Pantai (PPP) Tegalsari, Kota Tegal berfungsi untuk melindungi wilayah muara dari efek pendangkalan. Tinggi bangunan jetty Pelabuhan Perikanan Pantai Tegalsari, Kota Tegal memiliki tinggi bangunan sebesar 2,5 meter. Gelombang datang ke bangunan pantai akan dapat membangkitkan run-up gelombang, sehingga dapat mempengaruhi stabilitas dan efektivitas bangunan. Penelitian ini bertujuan untuk mengetahui tinggi run-up yang terjadi pada bangunan jetty di PPP Tegalsari, Kota Tegal. Pengumpulan data penelitian diawali dengan pengukuran dimensi jetty, pengukuran gelombang menggunakan $A D C P$ yang dipadukan dengan data angin ogimet selama 11 tahun (2009-2019), pengukuran batimetri dan data pasang surut PPP Tegalsari tahun 2020. Analisis tinggi run-up gelombang menggunakan perhitugan empiris Bilangan Irribaren. Hasil penelitian menunjukkan bahwa tinggi run-up gelombang pada Musim Barat pada jetty 0,64 m pada kondisi overtopping dengan $h-d s=0,57 \mathrm{~m}$, tinggi run up gelombang pada Musim Peralihan I sebesar $0,53 \mathrm{~m}$ pada kondisi non - overtopping dengan $h-d s=0,57 \mathrm{~m}$, tinggi run up gelombang pada Musim Timur pada jetty $0,52 \mathrm{~m}$ kondisi overtopping dengan $h-d s=0,57 \mathrm{~m}$, tinggi run up gelombang pada musim Peralihan II pada jetty sebesar $0,57 \mathrm{~m}$ dengan kondisi overtopping dengan $\mathrm{h}-\mathrm{ds}=0,57 \mathrm{~m}$. Jetty dikategorikan kedalam kondisi overtopping karena pada musim barat dan peralihan II karena nilai $h$ - $d s$ lebih kecil dibandingkan nilai run-up.
\end{abstract}

Kata kunci: Run-up, gelombang, overtopping, PPP Tegalsari

\begin{abstract}
The harbor jetty beach protection structure at Pelabuhan Perikanan Pantai (PPP), Tegal City serves to protect the estuary area from the shoaling effect. The jetty structure has 2,5 meters of height. The Waves along the jetty structure will generate wave run-up, which can affect the stability and effectiveness of the building. This study is focusing to determine the height of run - up that occurs on Pelabuhan Perikanan Pantai Tegalsari jetty structure. The research data collection begins with the measurement of the jetty dimensions, wave measurement using (Accoustic Doppler Current Profiler) ADCP combined with Ogimet wind data for 11 years (2009-2019), bathymetric measurements and tidal data of Pelabuhan Tegalsari in 2020. The run-up height analysis using empirical calculation of Irribaren number. The result of wave run - up height of the west Season is 0,64 m categorized as overtopping condition with h-ds $=0.57 \mathrm{~m}$, the wave run-up height in the first transitional season is 0,53 $\mathrm{m}$ categorized as non - overtopping condition with $h$ $d s=0.57 \mathrm{~m}$, wave run up height in East Season is 0,52 $\mathrm{m}$ as non - overtopping condition with $h$-ds $=0.57$ $m$, wave run-up height in second transition season is $0,57 \mathrm{~m}$ categorized as overtopping conditions where $h$-ds $=0,57 \mathrm{~m}$. Jetty of Pelabuhan Perikanan Pantai Tegalsari, city of Tegal is categorized into overtopping condition in west and second transition season because the $h$-ds value is smaller than the run-up value.
\end{abstract}

Keywords : Run-up, wave, overtopping, PPP Tegalsari 


\section{PENDAHULUAN}

Bangunan pelindung pantai jetty Pelabuhan Perikanan Pantai (PPP) Tegalsari, Kota Tegal berfungsi untuk melindungi wilayah muara dari efek pendangkalan. Jetty adalah bangunan pantai yang diletakkan pada kedua sisi muara sungai yang berfungsi untuk mengurangi pendangkalan oleh efek sedimentasi. Tinggi bangunan jetty Pelabuhan Perikanan Pantai Tegalsari, Kota Tegal setinggi 2,5 meter. Gelombang yang tertahan suatu rintangan akan terhenti, sedangkan elombang yang tidak tertahan akan merambat dan mengalami transformasi gelombang seperti penyebaran, pembelokan, dan perubahan tinggi gelombang (Dauhan et al., 2013; Imbar, S.E.J., 2020).

Fenomena overtopping sangat penting untuk dikaji terutama terhadap struktur bangunan pantai karena terkait dengan monitoring dan evaluasi struktur bangunan (Alfansuri et al., 2010). Gelombang yang menghempas bangunan pelindung pantai akan menimbulkan efek limpasan air yang merambat ke puncak bangunan. Berdasarkan hasil pengukuran langsung diperoleh nilai panjang keseluruhan jetty sebesar 295 $\mathrm{m}$, lebar penampang puncak jetty sebesar $1,5 \mathrm{~m}$, dan material penyusun jetty berupa batu pecah. Tinggi jetty yang dihitung dari mean sea level sebesar 2,5 $\mathrm{m}$ yang disajikan pada gambar 7 .

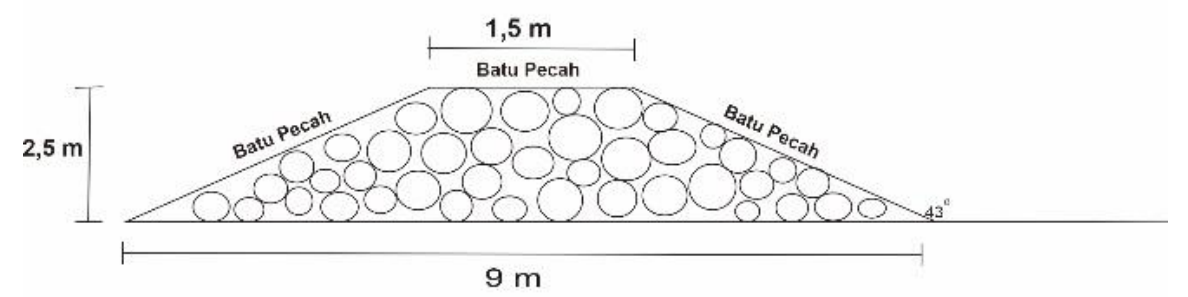

Gambar 1. Penampang Melintang Jetty

(Sumber : Pengukuran Lapangan 2020)

Elevasi overtopping tergantung pada struktur tinggi, kedalaman struktur kaki, dan struktur lereng (CERC, 1984). Gelombang yang datang dan menabrak struktur pelindung pantai akan menimbulkan efek run-up. Run-up gelombang adalah tinggi rayapan gelombang saat mengenai suatu struktur bangunan pantai (Triatmodjo,1999). Salah satunya adalah efek run-up gelombang yang timbul akibat rusaknya breakwater yang ada di ujung jetty sisi Barat PPP Tegal Sari. Bangunan jetty dapat mengalami overtopping run-up gelombang, akan mengakibatkan kerusakan pada konstruksi jetty. Kerusakan yang timbul akan menghilangkan fungsi dari bangunan jetty itu sendiri. Penelitian ini bertujuan untuk mengetahui tinggi runup yang terjadi pada bangunan jetty di Pantai Tegalsari, Kota Tegal. 


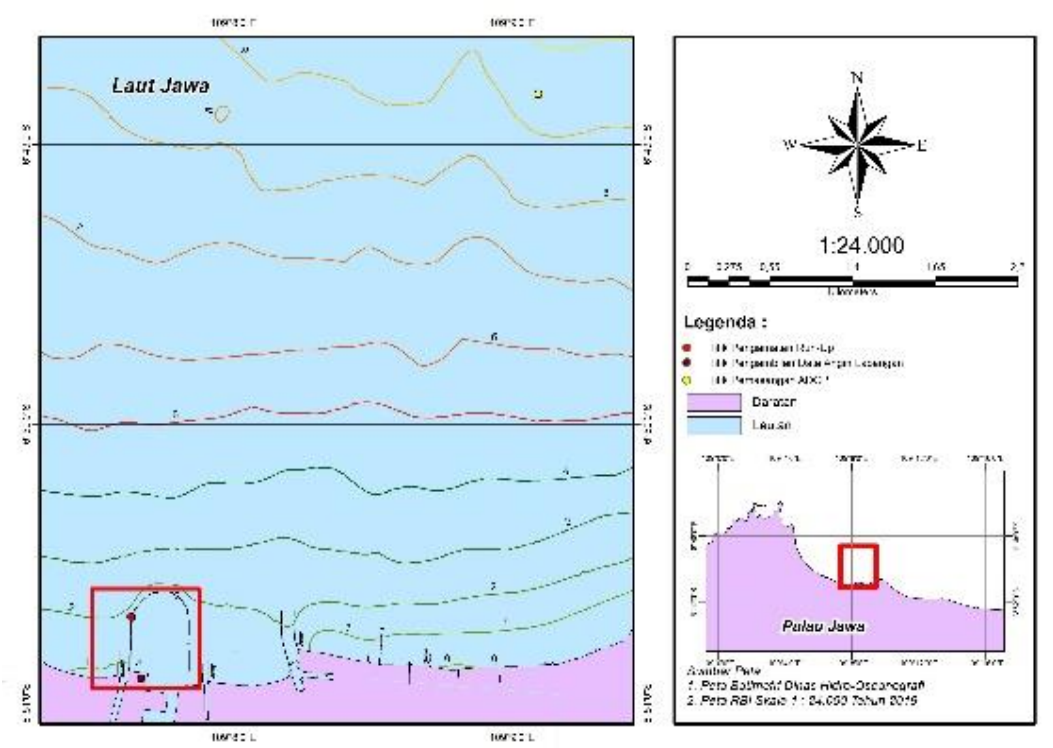

Gambar 2. Peta Lokasi Penelitian.

\section{MATERI DAN METODE}

(Sumber : Hasil Pengolahan Data, 2020)

Pengumpulan data penelitian diawali dengan pengukuran dimensi jetty, pengukuran gelombang menggunakan $A D C P$ pada koordinat $06^{\circ} 49^{\prime} 01.06^{\prime \prime} \mathrm{S}$ dan $109^{\circ} 09^{\prime} 35.12^{\prime \prime} \mathrm{S}$ selama 3 hari dengan selang waktu 10 menit pada tanggal 26 - 28 Agustus 2020 dan dilakukan pengukuran angin secara langsung di Pantai Tegalsari Kota Tegal dengan menggunanakan hand-anemometer dengan selang waktu 12 jam sekali pada 26 - 28 Agustus 2020 serta dilakukan pengambian angin ogimet selama 11 tahun (2009-2019) dari www.ogimet.com. Pengukuran batimetri PPP Tegalsari dari Dinas Hidro-Oseanografi serta peta Rupa Bumi Indonesia Skala $1: 25.000$ tahun 2019. Pengambilan data pasang surut dari tides.big.go.id PPP Tegalsari tahun 2020.

\section{Analisis Data}

Validasi data gelombang lapangan dengan data peramalan gelombang angin berdasarkan Purwanto $(2011)^{12}$ verifikasi dihitung menggunakan persamaan sebagai berikut :

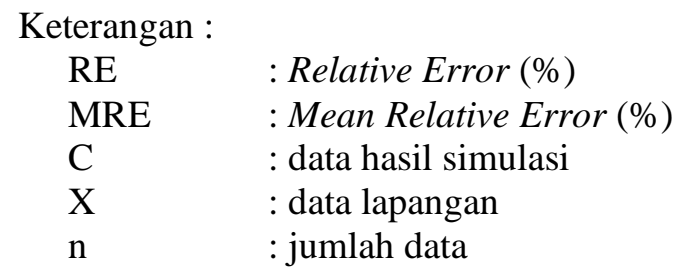

$$
\begin{gathered}
R E=\frac{|X-C|}{X} \times 100 \% \\
M R E={ }_{0}^{n} \Sigma \frac{|R E|}{|n|}
\end{gathered}
$$

Data gelombang yang didapat pada saat melakukan pengukuran dianalisa menggunakan metode gelombang representative berdasarkan Triatmodjo (1999) dengan mengimplementasikan data pengamatan dalam bentuk tinggi gelombang signifikan (Hs) dan periode signifikan (Ts) dengan persamaan sebagai berikut:

$$
\mathrm{N}=33,33 \% \mathrm{x} \text { jumlah data }
$$




$$
\begin{gathered}
H s=\frac{(H 1+H 2+. . H n)}{n} \\
T s=\frac{(T 1+T 2+. . T n)}{n}
\end{gathered}
$$

\section{Pengolahan Peramalan Gelombang dari Data Angin}

Perhitungan tinggi dan periode gelombang menggunakan data angin per-jam selama 11 tahun (20092019) yang diperoleh dari Ogimet. Peramalan gelombang yang digunakan dalam penelitian ini menggunakan metode Sugianto (2017) permusim selama 11 tahun dari tahun 2009-2019. Metode peramalan gelombang digunakan dengan menggunakan data angin yang diolah menggunakan metode Sugianto et al. (2017). Metode tersebut merupakan metode peramalan gelombang untuk Laut Jawa yang didasarkan pada pemodelan distribusi kecepatan angin dan kecepatan angin maksimum secara real time. Pemanfaatan pemodelan distribusi tersebut digunakan untuk mendapatkan hubungan empiris antara kecepatan angin dan tinggi gelombang di Laut Jawa.

\section{Pengolahan Data Pasang Surut}

Pengolahan data pasang surut menggunakan metode Admiralty untuk memperoleh konstanta harmonik pasang surut yang meliputi amplitudo (A), $\mathrm{M}_{2}, \mathrm{~S}_{2}, \mathrm{~K}_{1}, \mathrm{O}_{1}, \mathrm{~N}_{2}, \mathrm{~K}_{2}, \mathrm{P}_{1}, \mathrm{M}_{4}$. Metode Admiralty merupakan metode perhitungan data pasang surut selama 15 atau 29 piantan (Ongkosongo et. al., 1989). Dalam penelitian kali ini menggunakan data 30 hari.

Berdasarkan komponen harmonik pasang surut akan diperoleh:

1. $\quad$ Mean Sea Level (MSL)

$$
M S L=A\left(S_{0}\right)
$$

2. $\quad$ Lowest Lower Water Level (LLWL)

$$
L L W L=A\left(S_{0}\right)-\left(A\left(M_{2}\right)+A\left(S_{2}\right)+A\left(K_{1}\right)+A\left(O_{1}\right)+A\left(P_{2}\right)+A\left(K_{2}\right)\right)
$$

3. $\quad$ Highest High Water Level (HHWL)

$$
H H W L=A\left(S_{0}\right)+\left(A\left(M_{2}\right)+A\left(S_{2}\right)+A\left(K_{1}\right)+A\left(O_{1}\right)+A\left(P_{2}\right)+A\left(K_{2}\right)\right)
$$

4. Tipe Pasang

$$
\mathrm{F}=\quad \frac{K 1+01}{M 2+S 2}
$$

\section{Perhitungan Run-Up}

Run-up gelombang dihitung menggunakan hasil peramalan gelombang. Tinggi dan periode gelombang adalah tinggi signifikan Hs dan Ts rerata. Perhitungan run-up menggunakan bilangan irribaren, dimana untuk menentukan besaran run-up gelombang pada bangunan dengan permukaan miring untuk berbagai material (Triatmodjo, 1999).

Langkah perhitungan tinggi run-up sebagai berikut:

1. Dilakukan perhtingungan fungsi bilangan Irribaren utntuk berbagai jenis lapis lindung dengan persamaan:

\section{Dengan :}

$$
I r=\frac{t g \vartheta}{\left(\frac{H}{L o}\right)^{0,5}}
$$

Ir : Bilangan Irribaren

$H \quad$ : Tinggi gelombang di lokasi bangunan

$\vartheta \quad$ : Sudut kemiringan

$$
\text { Lo : Panjang gelombang laut dalam }
$$

2. Dilakukan pengeplotan pada grafik run-up gelombang berdasarkan nilai Irribaren (Ir);

3. Dilakukan Perhitungan nilai run-up gelombang. 


\section{Perhitungan Elevasi Puncak Bangunan Jetty} berikut:

Perhitungan elevasi puncak bangunan jetty dilakukan dengan menggunakan persamaan sebagai

$$
\text { Elevasi puncak }=H H W L+R u+\text { Tinggi Kebebasan }
$$

Hasil perhitungan run-up dan elevasi puncak bangunan dapat digunakan sebagai data acuan dalam monitoring dan evaluasi kinerja jetty di Pantai Tegalsari, Kota Tegal.

\section{HASIL DAN PEMBAHASAN \\ Gelombang}

Hasil Pengukuran dan pengolahan data gelombang lapangan yang diperoleh dari pengambilan data menggunakan ADCP selama 3 hari pada Musim Timur mendapatkan nilai tinggi gelombang representatif (Hs) sebesar 0,574 m, tinggi gelombang maksimum (Hmax) sebesar 0,849 $\mathrm{m}$, dan tinggi gelombang minimum (Hmin) sebesar 0,307 m. Periode gelombang Signifikan (Ts) sebesar 6,096 detik, periode maksimum (Tmaks) sebesar 8,3 detik, dan periode minimum (Tmin) sebesar 3,3 detik. Hasil di atas disajikan pada tabel 1 dan Gambar 3 - 4 .

Tabel 1. Tinggi dan Periode Gelombang Lapangan

\begin{tabular}{ccc}
\hline Gelombang & Tinggi (m) & Periode (s) \\
\hline Maksimum & 0.849 & 8.3 \\
\hline Signifikan & 0.574 & 6.096 \\
\hline Minimum & 0.307 & 3.3 \\
\hline \multicolumn{2}{c}{ (Sumber :Pengolahan Data, 2020) }
\end{tabular}

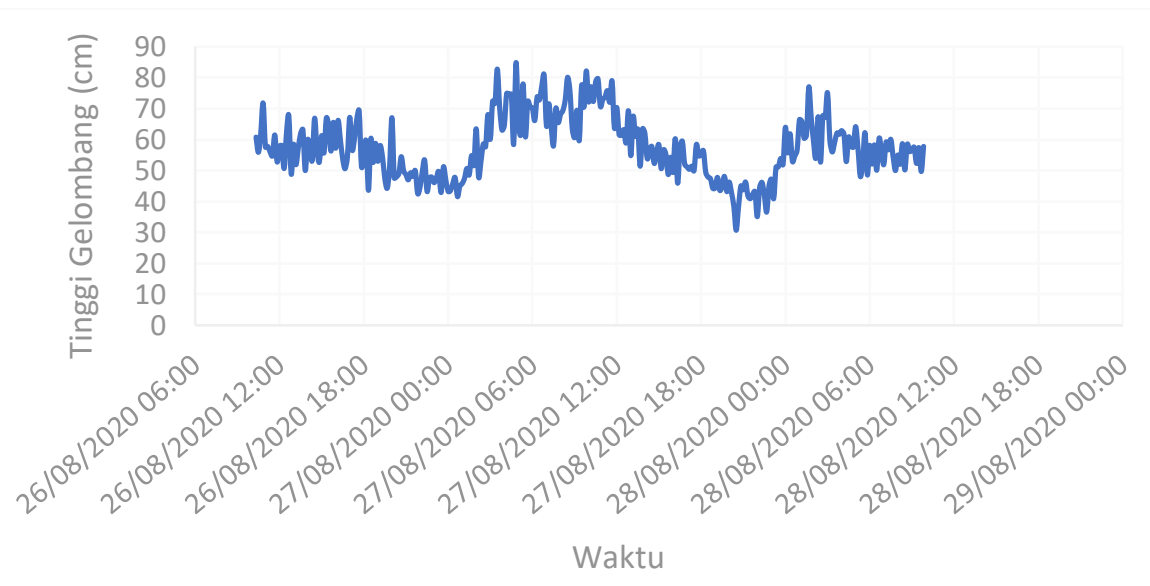

Gambar 3. Grafik Tinggi Gelombang Pengukuran Lapangan (26-28 Agustus 2020)

(Sumber : Pengolahan Data 2020) 


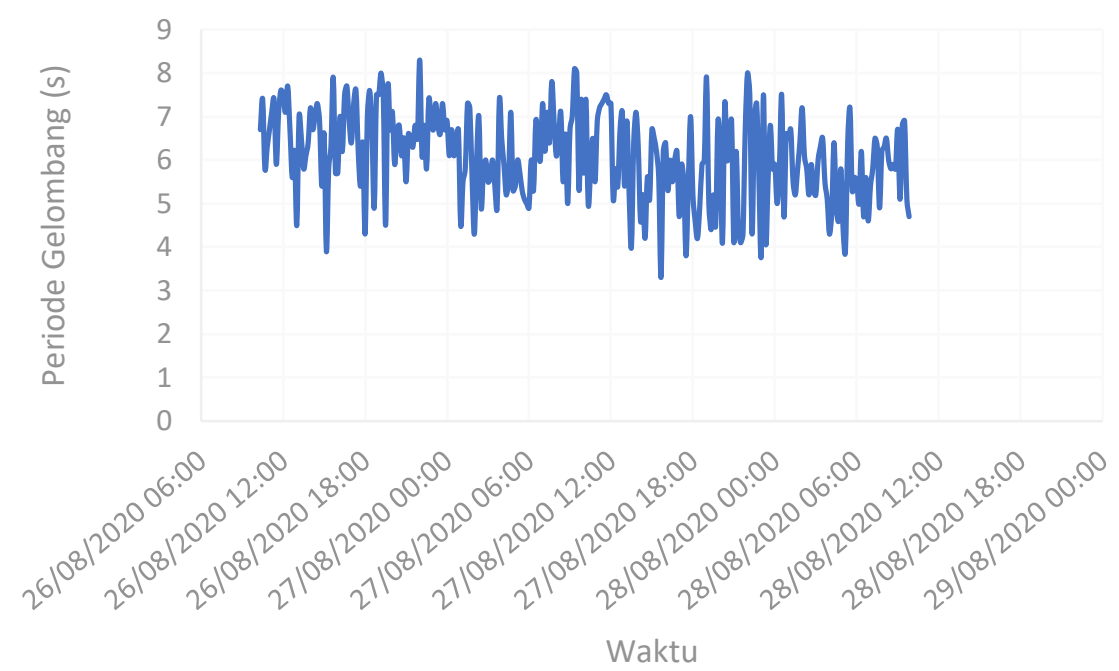

Gambar 4. Grafik Periode Gelombang Pengukuran Lapangan (26-28 Agustus 2020)

(Sumber : Pengolahan Data 2020)

Setelah diketahui nilai tinggi dan periode gelombang, dilakukan perhitungan parameter gelombang yang lain dengan menggunakan nilai tinggi signifikan gelombang $(\mathrm{Hs})$ dan periode signifikan gelombang (Ts). Berdasarkan pengolahan data untuk mengetahui parameter gelombang, gelombang di Perairan PPP Tegalsari dapat dikategorikan sebagai gelombang perairan transisi dengan nilai d/L sebesar 0,194. Berdasarkan CERC $(1984)^{2}$ nilai tersebut memenuhi syarat $0,05<\mathrm{d} / \mathrm{L}<0,5$ sehingga diklasifikasikan sebagai gelombang perairan transisi.

Data gelombang peramalan diperoleh dengan pengolahan data angin 11 tahun (2009-2019) stasiun perekaman wilayah Tegal menggunakan metode (Sugianto, 2014). Pada hasil pengolahan data peramalan gelombang pada musim timur didapatkan hasil berupa nilai tinggi gelombang signifikan (Hs) sebesar 0,391 $\mathrm{m}$ dan periode maksimum gelombang (Ts) sebesar 3,992 s.

Berdasarkan hasil perhitungan peramalan didapatkan nilai tinggi gelombang rata-rata dan periode rata-rata tertinggi terjadi pada musim peralihan II dengan nilai tinggi gelombang signifikan (Hs) sebesar 0,438 meter dan periode signifikan gelombang (Ts) sebesar 4,093 detik dengan arah datang gelombang $\left(\alpha_{0}\right)$ $23^{\circ}$. Sedangkan untuk nilai sudut datang gelombang yang dihitung berdasarkan arah angin dominan terhadap kontur dasar perairan didapatkan arah arah sudut datang gelombang pada musim barat sebesar $45^{\circ}$, musim peralihan I sebesar $39^{\circ}$, musim timur sebesar $39^{\circ}$, dan musim peralihan II sebesar $23^{\circ}$ perbandingan nilai tinggi gelombang signifikan dan periode gelombang signifikan disajikan dalam Gambar 5 dan 6.

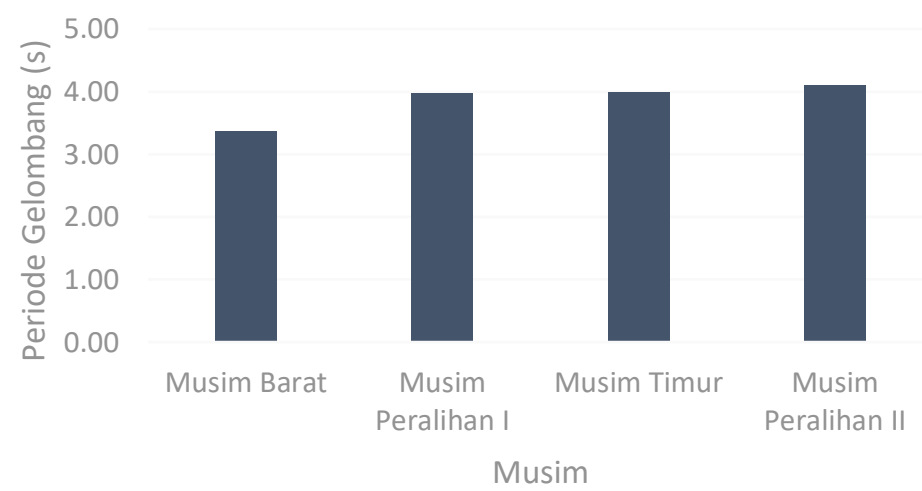

Gambar 5. Perbandingan Tinggi Gelombang Signifikan Peramalan

(Sumber : Pengolahan Data, 2020) 


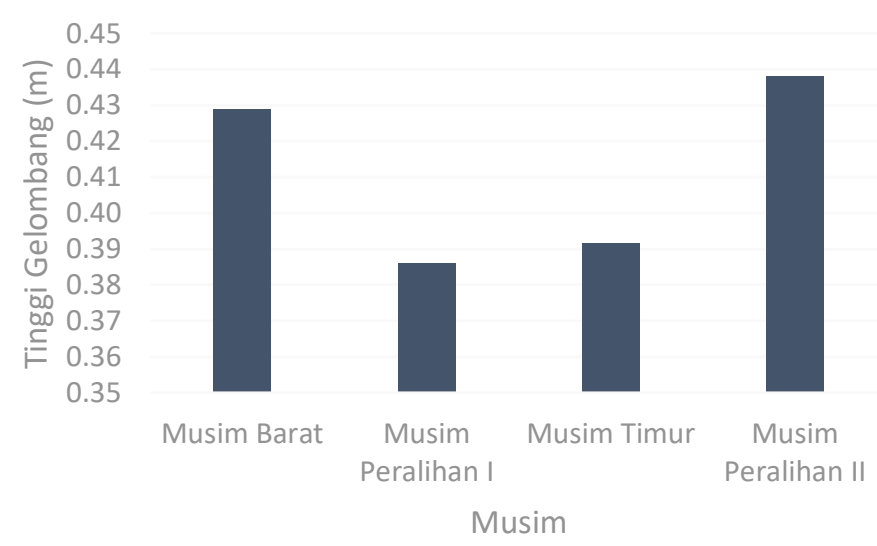

Gambar 6. Perbandingan Nilai Periode Signifikan Peramalan

(Sumber : Pengolahan Data, 2020)

\section{Validasi Data Lapangan dengan Data Peramalan Gelombang}

Validasi data dilakukan menggunakan data pengukuran lapangan pada tanggal 26-29 Agustus 2020 dan data hasil peramalan gelombang pada 26-28 agustus 2019. Validasi dilakukan menggunakan metode MRE yang membandingkan nilai gelombang pengukuran lapangan signifikan dengan nilai gelombang signifikan peramalan untuk mendapatkan nilai kesalahan relatif.

Berdasarkan hasil diatas didapatkan nilai persentase error tinggi signifikan gelombang antara gelombang lapangan dan gelombang peramalan sebesar 17,82\% dari Gambar 3 dan Gambar 5, sedangkan untuk periode gelombang didapatkan nilai error sebesar 20,86\% dari Gambar 4 dan Gambar 6. Sehingga kedua hasil tersebut dikategorikan ke dalam batas wajar nilai error sehingga data dapat dikatakan baik, kemudian data dapat digunakan untuk pengolahan data peramalan gelombang.

\section{Pasang Surut}

Data pasang surut selama 29 piantan menggunakan data dari BIG stasiun pengamatan Pekalongan. Penggunaan data pasang surut stasiun pengamatan pekalongan dipertimbangkan karena letak wilayah yang tidak terlalu jauh dari Kota Tegal dan mempunyai karakteristik perairan yang sama. Pengolahan data pasang surut menggunakan metode admiralty. Kemudian diperoleh nilai dari perhitungan komponen pasang surut berupa bilangan Formzahl (F) sebesar 1,45 sehingga dapat dikategorikan sebagai pasang surut campuran condong harian ganda. Selain itu didapatkan nilai dari Higher High Water Level (HHWL) sebesar 1,93 m, Higher Water Level (HWL) sebesar 1,91 m, Mean Sea Level (MSL) sebesar 1,41 m, Lower Low Water Level (LLWL) sebesar 0,95 m, dan Lowest Water Level (LWL) sebesar sebesar 1,02 m.

Tabel 2. Komponen kedudukan muka air

\begin{tabular}{lll}
\hline No & Pasang Surut & Nilai (m) \\
\hline 1 & HHWL & 1.93 \\
\hline 2 & HWL & 1,91 \\
\hline 3 & MSL & 1.41 \\
\hline 4 & LWL & 1,02 \\
\hline 5 & LLWL & 0.95 \\
\hline
\end{tabular}

(Sumber : Pengolahan Data 2020) 

Gambar 7.

Grafik pasang surut bulan Agustus 2019 perairan Pekalongan selama 29 piantan disajikan pada

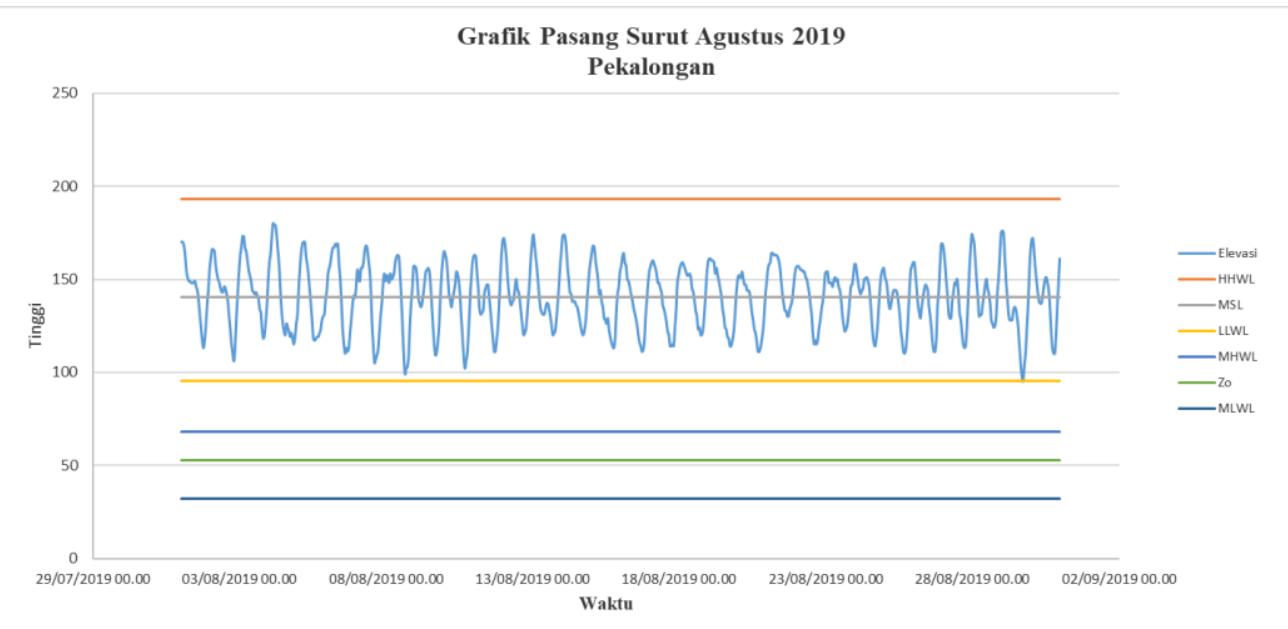

Gambar 7. Grafik Pasang Surut Perairan Pekalongan (Sumber : Pengolahan Data, 2020)

\section{Run-Up Gelombang}

Hasil perhitungan nilai run-up gelombang dalam hal ini menggunakan perhitungan nilai irribaren dari tiap musim untuk mengetahui tingkat overtopping yang terjadi pada tiap musim. Data yang digunakan untuk menghitung nilai run-up adalah data tinggi gelombang dari masing-masing musim yaitu musim barat, peralihan I, musim timur, dan musim peralihan II. Selain itu data tinggi gelombang pada pengukuran lapangan juga turut digunakan untuk menghitung nilai run-up pada waktu pengambilan data.

Berdasarkan pengolahan data diperoleh nilai run-up yang terjadi pada musim barat sebesar 0,64 meter, pada musim peralihan I sebesar 0,53 meter, pada musim timur sebesar 0,52 meter, pada musim peralihan II sebesar 0,57 meter, dan pada saat pengambilan data lapangan sebesar 0,76 meter dengan nilai muka air rencana $(D W L)$ pada musim barat sebesar 2,06 m, musim peralihan I sebesar 2,55 m, musim timur sebesar 2,05 m, dan musim peralihan II sebesar 2,07 m. Nilai tersebut kemudian dihubungkan dengan selisih nilai tinggi bangunan dan kedalaman lokasi bangunan $(h-d s)$. Apabila nilai run-up lebih besar dari selisih tinggi bangunan dan kedalaman lokasi bangunan makan dikategorikan sebagai keadaan overtopping. Berdasarkan pengolahan data, pada musim barat dan peralihan II dikategorikan ke dalam kondisi overtopping karena nilai run-up lebih besar daripada selisih tinggi bangunan dan kedalaman lokasi bangunan pada setiap musim. Sedangkan pada musim peralihan I dan musim timur dikategorikan ke dalam kondisi non-overtopping.

Tabel 3. Elevasi Bangunan Rencana

\begin{tabular}{lc}
\hline \multicolumn{1}{c}{ Musim } & $\begin{array}{c}\text { Elevasi Bangunan } \\
\text { Rencana }(\mathbf{m})\end{array}$ \\
\hline Barat & 3,2 \\
\hline Peralihan I & 3,6 \\
\hline Timur & 3,1 \\
\hline Peralihan II & 3,1 \\
\hline
\end{tabular}

Berdasarkan data perhitungan nilai run-up dilakukan perhitungan nilai elevasi puncak rencana bangunan jetty untuk dijadikan referensi penerapan tinggi bangunan jetty agar tidak terjadi overtopping. Data hasil perhitungan elevasi puncak rencana disajikan dalam Tabel 3. 


\section{KESIMPULAN}

Run - up gelombang pada penelitian yang dilakukan di PPP Tegalsari, Tegal memiliki tinggi run up pada musim barat $0,64 \mathrm{~m}$, pada musim peralihan $\mathrm{I} 0,53 \mathrm{~m}$, pada musim timur $0,52 \mathrm{~m}$, dan pada musim peralihan II 0,57 m dengan nilai muka air rencana $(D W L)$ pada musim barat sebesar 2,06 m, musim peralihan I sebesar 2,55 m, musim timur sebesar 2,05 m, dan pada musim peralihan II sebesar 2,07 m.

Berdasarkan nilai run - up yang diperoleh melalui pengolahan data, maka dapat dikategorikan pada musim barat dan musim peralihan II terjadi overtopping, sedangkan pada musim peralihan I, dan musim timur tidak terjadi overtopping pada bangunan jetty Pelabuhan Perikanan Pantai Tegalsari, Kota Tegal.

\section{UCAPAN TERIMA KASIH}

Ucapan terima kasih kepada civitas akademika Departemen Oseanografi, Fakultas Perikanan dan Ilmu Kelautan, Universtas Diponegoro dan Pihak Otorita Pelabuhan Perikanan Tegalsari Kota Tegal.

\section{DAFTAR PUSTAKA}

Alfansuri, Sholihin., Suntoyo , Haryo Dwito Armono. 2010. Analisa Perbandingan Formula Runup Dan Overtopping Untuk Gelombang Irregular Pada Struktur Dasar Kasar. Teknik Kelautan ITS. Surabaya

CERC. 1984. Shore Protection Manual Volume I. US Army Corps of Engineer. Washington D.C.

Dauhan, Stefani Kristie., Hansje Tawas., Hanny Tangkudung., Jeffry D. Mamoto. 2013. Analisis Karakteristik Gelombang Pecah Terhadap Perubahan Garis Pantai Di Atep Oki. Jurnal Sipil Statik. 1(12): 784-796

Defant, A. 1985. Natural Science ; Ebb and Flow The Tides of Earth, Air and Water. The University of Michigan Press, Michigan.

Hutabarat, S. dan S.M. Evans. 1985. Pengantar Oseanografi Edisi Ke-2. Universitas Indonesia Press, Jakarta.

Imbar, Sesty, E.J. 2020. Analisis Deformasi Gelombang Pada Pantai Minahasa Barat. Jurnal Sipil Statik. 8 (1): $65-70$

Lekatompessy, Sonja T.A. dan Alfredo Tutuhatunewa. 2010. Kajian Konstruksi Model Peredam Gelombang Dengan Menggunakan Mangrove Di Pesisir Lateri - Kota Ambon. Jurnal ARIKA, 4 (1): 51-60. ISSN: 1978-1105

Loupatty, Grace. 2013. Karakteristik Energi dan Arus Perairan di Provinsi Maluku. Fisika FMIPA UNPATTI, Maluku. 7 (1) : 19-22

Ongkosongo, O. S. R. dan Suyarso. 1989. Pasang - Surut. Pusat Penelitian dan Pengembangan Oseanologi (P3O) LIPI. Jakarta.

Pamungkas, A. (2018). Karakteristik parameter oseanografi (pasang-surut, arus, dan gelombang) di perairan utara dan selatan Pulau Bangka. Buletin Oseanografi Marina, 7(1), 51-58.

Pemkot Tegal. 2014. Kondisi Geografis Kota Tegal. http://www.tegalkota.go.id. Diakses Pada 17 Mei 2019

Poerbandono dan Djunarsjah, E. 2005. Survei Hidrografi. Refika Aditama. Bandung.

Purwanto. 2011. Analisa Spektrum Gelombang Berarah di Perairan Pantai Kuta, Kabupaten Badung, Bali. Buletin Oseanografi Marina, 1: 45-59.

Solihuddin, Tb. 2011. Karakteristik Pantai dan Proses Abrasi di Pesisir Padang Pariaman, Sumatera Barat. Puslitbang Sumberdaya Laut dan Pesisir, Balitbang Kelautan Perikanan - KKP. Vol. 13 (2) : 112 $-120$

Sugianto, D. N., S. Widada, A. Wirasatriya, A. Ismanto, A. Darari and Suripin. 2017. Modelling Of Suspended Sediment Transport in Coastal Demak Indonesia By Using Currents Analyzing. ARPN Journal of Engineering and Applied Sciences 12 (16):4666-4678.

Triatmodjo, Bambang.1999. Teknik Pantai. Beta Offset. Yogyakarta. 